\title{
Effect of Biofertilizer in Organic and Conventional Systems on Growth, Yield and Baking Quality of Hard Red Winter Wheat
}

\author{
Ammar Al-Zubade ${ }^{1,2, *}$, Timothy Phillips ${ }^{3}$, Mark A. Williams ${ }^{1}$, Krista Jacobsen ${ }^{1}$ (D) and David Van Sanford ${ }^{3}$ \\ 1 Department of Horticulture, University of Kentucky, 1100 South Limestone Street, Lexington, KY 40646, USA; \\ mark.williams@uky.edu (M.A.W.); krista.jacobsen@uky.edu (K.J.) \\ 2 Department of Field Crops Sciences, College of Agricultural Engineering Sciences, University of Baghdad, \\ Baghdad 10071, Iraq \\ 3 Department of Plant and Soil Sciences, University of Kentucky, 1405 Veterans Drive, \\ Lexington, KY 40546, USA; tim.phillips@uky.edu (T.P.); dvs@uky.edu (D.V.S.) \\ * Correspondence: ammar.alzubade@uky.edu; Tel.: +1-859-420-2235
}

Citation: Al-Zubade, A.; Phillips, T.; Williams, M.A.; Jacobsen, K.; Van Sanford, D. Effect of Biofertilizer in Organic and Conventional Systems on Growth, Yield and Baking Quality of Hard Red Winter Wheat. Sustainability 2021, 13, 13861 https://doi.org/10.3390/su132413861

Academic Editor: Sean Clark

Received: 16 November 2021 Accepted: 13 December 2021 Published: 15 December 2021

Publisher's Note: MDPI stays neutral with regard to jurisdictional claims in published maps and institutional affiliations.

Copyright: () 2021 by the authors. Licensee MDPI, Basel, Switzerland. This article is an open access article distributed under the terms and conditions of the Creative Commons Attribution (CC BY) license (https:// creativecommons.org/licenses/by/ $4.0 /)$.

\begin{abstract}
A two-year study (harvest years 2019 and 2020) was conducted to investigate the effect of a commercially available biofertilizer, in combination with variable nitrogen $(\mathrm{N})$ rate, on bread baking quality and agronomic traits in hard winter wheat grown in conventional (CONV) and organic (ORG) farming systems in Kentucky, USA. The hard red winter wheat cultivar 'Vision 45' was used with three $\mathrm{N}$ rates $(44,89.6$ and $134.5 \mathrm{~kg} / \mathrm{ha}$ as Low, Med and High, respectively) and three biofertilizer spray regimes (no spray, one spray and two sprays). All traits measured were significantly affected by the agricultural production system (CONV or ORG) and $\mathrm{N}$ rate, although trends in their interactions were inconsistent between years. In $\mathrm{Y} 2$, yield was greatest in treatments with high $\mathrm{N}$ rates and in the ORG system. Biofertilizer treatments had a negative to neutral effect on grain yield. Baking quality traits such as protein content, lactic acid solvent retention capacity and sedimentation value (SV) were consistently greater in the CONV system and increased with the higher $\mathrm{N}$ application rates. Similarly, biofertilizer application had no effect on predictive baking quality traits, except for SV in year 1 of the study, where it increased with two sprays. Loaf volume was consistently greater from wheat grown in CONV treatments. From these results, we conclude that further research is warranted to evaluate the potential for biofertilizers to enhance $\mathrm{N}$ uptake and affect bread baking quality or other end-use traits. Additional research may be especially useful in organic production systems where biologically based $\mathrm{N}$ fertilizers are utilized, and treatments were not negatively affected by biofertilizer applications. Such strategies may be needed to increase protein quantity and gluten quality to optimize winter wheat production for bread baking qualities in the southeastern USA.
\end{abstract}

Keywords: effective microorganism; organic fertilizer; bread baking quality; nitrogen fertilizer

\section{Introduction}

Hard red winter (HRW) wheat (Triticum aestivum L.) makes up approximately $40 \%$ of the total wheat cultivated in the US [1]. HRW is mostly grown in the Great Plains region, which is characterized by dry sub-humid and semi-arid weather conditions [2]. HRW grain has a high protein content that results in flour typically used for bread production. However, it has a lower yield potential [3] than soft red winter (SRW) wheat. SRW is widely adapted to grow in high-rainfall, moist, sub-humid regions such as the eastern US and typically produces higher-yielding but lower protein content flour than HRW. Due to the low protein content, SRW flour is not generally used for bread baking [4], but it is best suited to the production of cakes, pastries, crackers, and cookies [5].

In light of the growth in the local and regional food movement in the US, there is increased interest from farmers and end users in local small grain value chains. Local grains provide benefits that go beyond their flavor. They are an important component of sustainable farming systems from an agricultural standpoint in that they reduce soil 
erosion by providing ground cover during the winter and reduce $\mathrm{N}$ contamination of the groundwater by scavenging available $\mathrm{N}$ [6]. In addition, economically, they support local farmers and decrease food miles. Moreover, from a social perspective, they benefit by increasing accountability of agricultural enterprises to local communities [7]. Thus, in Kentucky, artisan bakers are looking for a stable flour source from wheat that is grown locally and meets the requirement of consumers.

Protein content and protein quality are important considerations in assessing the baking quality of wheat used in bread baking. Improving protein and other baking quality traits may be accomplished through multiple strategies, including variety selection, and finding locally adapted HRW varieties that will perform in the eastern US. Agronomic practices such as integrated plant nutrition, crop rotation and nitrogen fertilization management are also important. Nitrogen is a critical element that is required by plants in larger amounts than other nutrients. $\mathrm{N}$ deficiency can have a significant impact on crop development and production. Therefore, to achieve an optimal yield, the $\mathrm{N}$ supply should be available according to the plant's needs and in the optimal form [8].

Biofertilizers are preparations containing strains of micro-organisms, organic products and dead tissues of plants which give nutrients to the soil as well as plants [9]. With the increase in sustainable agriculture around the world, bio-inoculants and biofertilizers have emerged as a new technique to improve crop production and quality. Use of biofertilizers has been promoted as a promising technique that may reduce the use of synthetic fertilizers, pesticides and input costs [10]. Biofertilizers induce many biochemical transformations in soil, such as: mineralization of organically bound forms of nutrients, exchange reactions, fixation of atmospheric nitrogen and other changes resulting in increased accessibility to soil nutrients [11].

Previous work has demonstrated that biofertilizers may have a positive effect on crop quality (Figure 1). Karthikeyan et al. [12] reported that the use of Pseudomonas fluorescens and Bacillus megaterium significantly increased alkaloid content in Catharanthus roseus (L.), which has medicinal importance as a producer of anticancer dimeric alkaloids Similarly, Khalid et al. [13] and Taie et al. [14] found that spinach and soybean produced with the use of different biofertilizers had higher total phenolic content, which confers health benefits, than the uninoculated control. In small grains, biofertilizers have been suggested to upregulate two high-quality protein subunits, i.e., the $81 \mathrm{kDa}$ high-molecular-weight glutenin subunit and the $43.6 \mathrm{kDa}$ low-molecular-weight glutenin subunit, which are important parameters for end-use quality. At the same time, biofertilizers enhance the activity of enzymes involved in organic matter decomposition and nutrient release [15]. Furthermore, there is a global trend toward using biofertilizers as they have longer lasting impact towards sustainable agriculture in reducing problems associated with the use of chemicals fertilizers [16].

The main objective of this two-year study was to evaluate how biofertilizers used in combination with organic and/or inorganic fertilizers would affect yield, protein content and end-use baking quality traits in HRW grown in central Kentucky. 


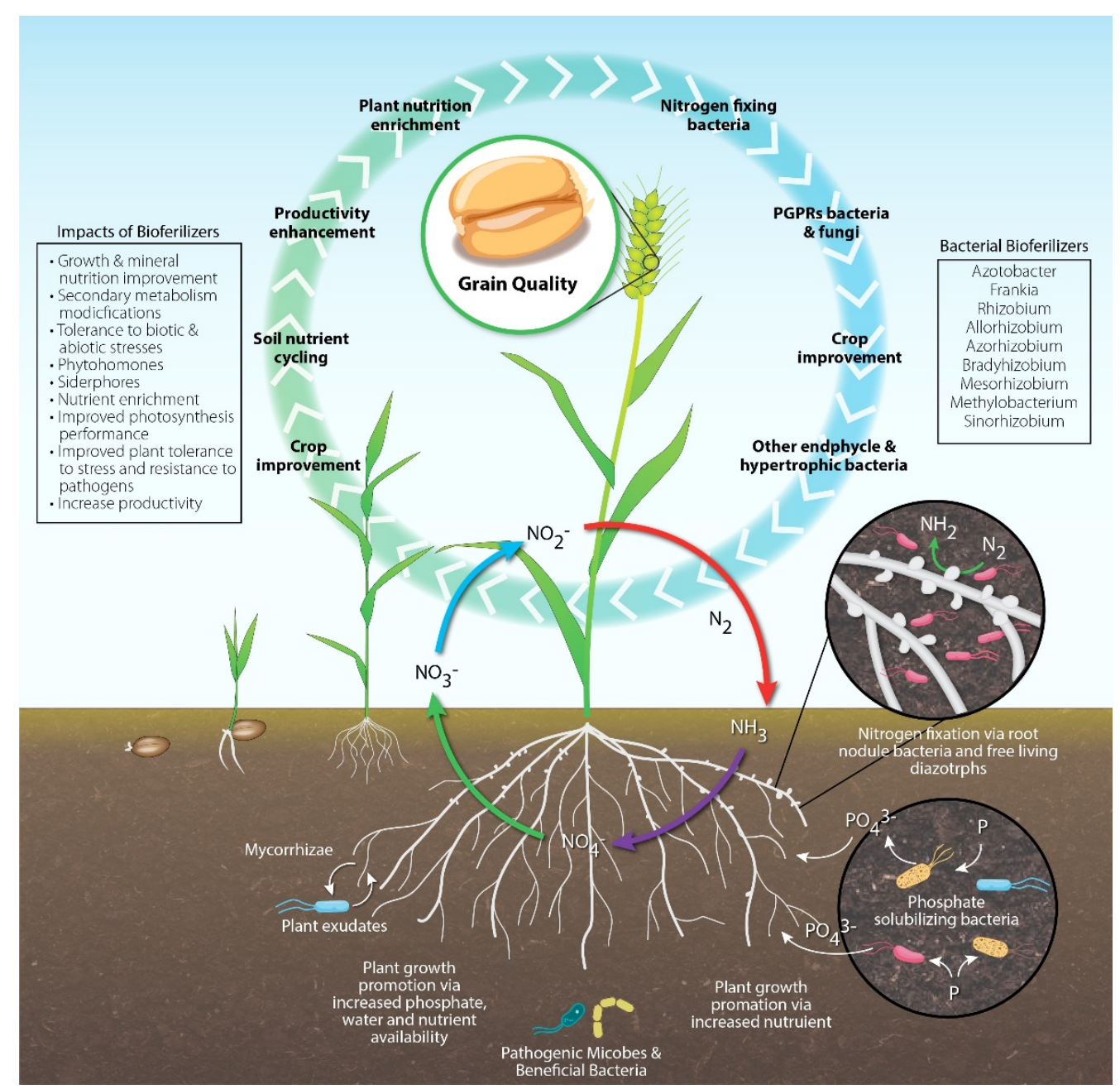

Figure 1. Biofertilizers and their proposed roles in improving agroecosystem functioning, crop yield and quality. (Illustration by Matthew Hazzard, College of Medicine, University of Kentucky).

\section{Materials and Methods}

\section{Experimental Design and Management}

This study was conducted at the University of Kentucky Horticulture Research Farm, in Lexington, KY, USA $\left(37^{\circ} 9^{\prime} 74.6 .34^{\prime \prime} \mathrm{N}, 84^{\circ} 53.45 .52^{\prime \prime} \mathrm{W}\right)$ during the 2018-2019 (Y1) and 2019-2020 (Y2) growing seasons. The mean air temperature in 2018 was $13.4{ }^{\circ} \mathrm{C}$ with a minimum of $-18.6^{\circ} \mathrm{C}$ recorded during the growing season. Annual precipitation in 2018 was $1760 \mathrm{~mm}$. Mean temperature in 2019 was $13.8^{\circ} \mathrm{C}$ with a minimum of $-16.4^{\circ} \mathrm{C}$ recorded during the growing season. Annual precipitation in 2019 was $1503 \mathrm{~mm}$ (Kentucky Climate Center, Bowling Green, KY, USA). The soil type was a Bluegrass-Maury silt loam (Fine, mixed, active, mesic oxyaquic paleudalf). Hard red winter wheat (Triticum aestivum L.) cultivar 'Vision 45' was planted on 24 October 2018 and 25 October 2019. Treatment factors included cropping system, nitrogen rate and biofertilizer spray regime.

The experiment was a randomized complete block design with cropping system, biofertilizer spray and nitrogen application rate as treatment factors. Treatments were arranged within fields of each cropping system (one field conventional, one field organic) with four replications. Plots measuring $5.5 \mathrm{~m}^{2}(4.6 \mathrm{~m} \times 1.2 \mathrm{~m})$ were planted with six crop rows. Weeds were monitored by weekly scouting and managed according to standard practice for each system. Weeds were not above the economic threshold in the CONV plots in either year, so no herbicide was applied. In ORG, however, weeds were controlled using hand cultivation at Feekes growth stage 6 [17] (BBCH growth stage 3 [18]), in early April of 
each year. The ORG field was managed following the USDA National Organic Program rules but was not certified organic [19].

Nitrogen $(\mathrm{N})$ sources were selected based on conventional and organic management specifications. Urea $(46 \% \mathrm{~N})$ was used for all applications in the CONV system, and a granular organic fertilizer (10\% N, NatureSafe 10-2-8, Darling Ingredients, Inc., Irving, TX, USA) in the ORG system. Three $\mathrm{N}$ regimes, representing low, medium and high rates (44, 89.6 and $134.5 \mathrm{~kg} / \mathrm{ha}$, respectively), were applied in a split within fields of each cropping system. Both systems fields received three $\mathrm{N}$ rates according to growth stage, for ORG (pre-plant, Feekes $3(\mathrm{BBCH} 2)$ and $6(\mathrm{BBCH} 3)$ ) and for CONV (Feekes 3, 6 and $10(\mathrm{BBCH} 6)$ ) as described in Table 1.

Table 1. Dates of biofertilizer and nitrogen fertilizer application for the growing seasons 2018-2019 (Y1) and $2019-2020$ (Y2).

\begin{tabular}{|c|c|c|c|c|c|}
\hline & & \multicolumn{4}{|c|}{ System } \\
\hline \multicolumn{2}{|c|}{ Treatments } & \multicolumn{2}{|c|}{ ORG } & \multicolumn{2}{|c|}{ CONV } \\
\hline & & Y1 & $\mathrm{Y} 2$ & Y1 & $\mathrm{Y} 2$ \\
\hline \multirow{4}{*}{ EM Spray } & No spray & $\mathrm{N} / \mathrm{A}$ & $\mathrm{N} / \mathrm{A}$ & $\mathrm{N} / \mathrm{A}$ & $\mathrm{N} / \mathrm{A}$ \\
\hline & One Spray & 24 October 2018 & 3 November 2019 & 24 October 2018 & 3 November 2019 \\
\hline & & 24 October 2018 & 3 November 2019 & 24 October 2018 & 3 November 2019 \\
\hline & Two Sprays & and 23 March 2019 & and 8 March 2020 & and 23 March 2019 & and 8 March 2020 \\
\hline \multicolumn{2}{|c|}{ Nitrogen applications } & $\begin{array}{l}5 \text { October 2018, } \\
12 \text { March } 2019 \text { and } \\
10 \text { April } 2019\end{array}$ & $\begin{array}{c}18 \text { October } 2019, \\
7 \text { March } 2020 \text { and } \\
6 \text { April } 2020\end{array}$ & $\begin{array}{c}12 \text { March } 2019, \\
10 \text { April } 2019 \text { and } \\
2 \text { May } 2019\end{array}$ & $\begin{array}{l}7 \text { March } 2020, \\
6 \text { April } 2020 \text { and } \\
20 \text { April } 2020\end{array}$ \\
\hline
\end{tabular}

Biofertilizer consisting of an effective microorganism (EM) consortium of species of photosynthetic and lactic acid bacteria and yeasts (AG1000, Teraganix, South Alto, TX, USA) was applied in three spray regimes (no spray, one spray and two sprays). This commercial biofertilizer was selected due the approval for use in both conventional and certified organic systems. Biofertilizer was diluted to a 1:12.5 ratio of biofertilizer to water, according to the label recommendations and applied by backpack sprayer to the growing plants and surrounding soil. For both systems, the first sprays were applied within one week of planting, while the second sprays were applied at Feekes growth stage 3 (BBCH 2) (Table 1). Plots were harvested in late July (27 July 2019 and 26 July 2020) using a Hege $125^{\circ} \mathrm{C}$ plot combine (Hege Company, Waldenburg, Germany).

The Feekes and $\mathrm{BBCH}$ scales were used to record growth stages including heading date (HD) and plant height (PH). Heading date (HD; Julian) was determined for each system when more than $50 \%$ of the spikes within a plot had emerged from the flag leaf sheath. Plant height $(\mathrm{PH} ; \mathrm{cm})$ was measured from the soil surface to the top of the spike, excluding awns in late May. Thousand kernel weight (TKW) was used in combination with grain yield to estimate kernel number. Yield was calculated from plot yields, adjusted to $13.5 \%$ moisture; this trait and test weight $(\mathrm{Kg} / \mathrm{ha}$ ) were measured using a GAC $2100 \mathrm{~b}$ grain analysis computer (Dickey-John, Auburn, IL, USA). Thousand kernel weights were measured using an ESC-1 seed counter (Agriculex Inc., Ontario, ON, Canada).

Grain quality traits included sedimentation value (SV, $\mathrm{mL})$, protein content $(\%)$ and predicted Lactic acid solvent retention capacity (SRC\%). SV $(\mathrm{mL})$ and SRC $(\%)$ are indicators of gluten strength in wheat flour of mill and baker's products [20]. SV(mL) was measured after the method of Dick and Quick [21], while grain protein and lactic acid content were measured from a $50 \mathrm{~g}$ subsample of grain from each plot using near infrared reflectance (NIR) (DA 7250, Perten Instrument, Hagersten, Sweden).

Bread loaves were made from flour that was milled on a Mockmill 100 Stone Grain Mill (Mockmill, Fairfield, IA, USA) immediately prior to mixing. Bread dough consisted of whole wheat flour $(200 \mathrm{~g})$, salt $(4 \mathrm{~g})$, commercial bread yeast $(0.75 \mathrm{~g})$ and water $(140 \mathrm{~g})$. Dough was mixed for $10 \mathrm{~min}$ on speed 1 of a Kitchenaid 4qt mixer and allowed to rest for $15 \mathrm{~min}$ and then, to strengthen the gluten, was subjected to 3 sets of folding $15 \mathrm{~min}$ 
apart, covered and fermented at 5 degrees ${ }^{\circ} \mathrm{C}$ for $24 \mathrm{~h}$. The dough was then removed from refrigeration and placed at room temperature $\left(23\right.$ degrees $\left.{ }^{\circ} \mathrm{C}\right)$ for $45 \mathrm{~min}$. The dough was then shaped into loaves and placed in loaf pans lined with baking parchment to prevent sticking. Shaped loaves were allowed to proof for $45 \mathrm{~min}$. Loaves were then baked at $246^{\circ} \mathrm{C}$ for $25 \mathrm{~min}$ in electric ovens. After baking, loaves were allowed to cool for $15 \mathrm{~min}$, then removed from the pans and analyzed for loaf height, weight and volume. Loaf volume was measured using a Volumeter instrument which measured volume of canola seed displaced by the loaf (National Manufacturing Co., Lincoln, NE, USA) after the method of Teferra [22].

Analysis of variance (ANOVA) was performed using a linear mixed model (PROC GLIMMIX, SAS 9.4, SAS Institute, Cary, NC, USA). Data were analyzed as a split plot, with cropping system by EM spray as the main plot factor and $\mathrm{N}$ rate application as the split-plot factor. The study was analyzed separately by year to account for differences between crop rotation and year-to-year variation in weather conditions. Nitrogen rate, system, EM spray and all possible interactions were fixed effects and the interaction between system, EM spray and replicate was a random effect. Mean comparison analysis for main effects and interactions were calculated using Tukey's test (HSD) at the 0.05 level. ANOVA results for agronomic and baking quality characteristics for both study years are presented in Table A1, Appendix A.

\section{Results}

\subsection{Plant Height}

Plants were consistently taller in the CONV treatments than in the ORG Med N and Low $\mathrm{N}$, although they did not differ from the ORG High $\mathrm{N}$ treatment (Table 2). Plants grown in ORG Med N were taller than ORG Low N by 3.6\% and 4.2\% for 2019 and 2020, respectively. The main effect was detected in the EM spray for both Y1 and Y2, where two sprays increased plant height by $2.8 \%$ over the control (Table 3 ). The one-spray treatment did not differ significantly from the control or the two-spray treatment. Significant systemspray interactions were observed only in Y1 (Table 4); plants within the CONV system did not show statistical difference, however, CONV treatments differed from ORG one and no spray but not from the ORG two spray treatment. Within the ORG system, no statistical difference was observed between the one- and two-spray treatments. In addition, the ORG no spray treatment had the lowest mean plant height of all treatments, though it was not significantly different from ORG one spray.

Table 2. Mean value for plant height $(\mathrm{cm})$, yield $(\mathrm{kg} / \mathrm{ha})$ and protein content $(\%)$ for system by rate interaction. Means with the same letters within each column and main effect are not significantly different, based on Tukey's HSD test performed at $\alpha=0.05$.

\begin{tabular}{cccccc}
\hline \multirow{2}{*}{ System } & \multirow{2}{*}{ Rate } & \multicolumn{2}{c}{ Mean Plant Height (cm) } & Mean Yield (kg/ha) & \multicolumn{2}{c}{ Mean Protein Content (\%) } \\
\cline { 3 - 6 } & & Y1 & Y2 & Y2 & Y1 \\
\hline CONV & High N & $101.18 \mathrm{a}$ & $93.56 \mathrm{a}$ & $4794.05 \mathrm{~b}$ & $12.88 \mathrm{a}$ \\
CONV & Med N & $100.54 \mathrm{a}$ & $92.92 \mathrm{a}$ & $4500.72 \mathrm{bcd}$ & $11.96 \mathrm{~b}$ \\
CONV & Low N & $99.91 \mathrm{a}$ & $92.29 \mathrm{a}$ & $4083.64 \mathrm{~cd}$ & $11.05 \mathrm{c}$ \\
ORG & High N & $100.33 \mathrm{a}$ & $92.49 \mathrm{a}$ & $5512.83 \mathrm{a}$ & $10.54 \mathrm{~cd}$ \\
ORG & Med N & $96.73 \mathrm{~b}$ & $89.11 \mathrm{~b}$ & $4623.69 \mathrm{bc}$ & $10.19 \mathrm{de}$ \\
ORG & Low N & $93.34 \mathrm{c}$ & $85.51 \mathrm{c}$ & $4022.61 \mathrm{~d}$ & $9.85 \mathrm{e}$ \\
\hline
\end{tabular}




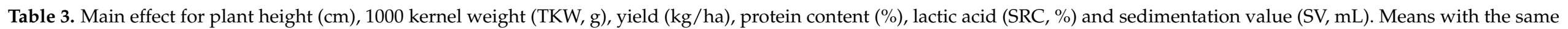
letters within each column and main effect are not significantly different, based on Tukey's HSD test performed at $\alpha=0.05$.

\begin{tabular}{|c|c|c|c|c|c|c|c|c|c|c|c|c|c|}
\hline \multirow{2}{*}{\multicolumn{2}{|c|}{ Main Effect }} & \multicolumn{2}{|c|}{ Plant Height $(\mathrm{cm})$} & \multicolumn{2}{|c|}{ TKW (g) } & \multicolumn{2}{|c|}{ Yield (kg/ha) } & \multicolumn{2}{|c|}{ Protein Content (\%) } & \multicolumn{2}{|c|}{ SRC (\%) } & \multicolumn{2}{|c|}{ SV $(\mathrm{mL})$} \\
\hline & & \multicolumn{2}{|c|}{ Mean } & \multicolumn{2}{|c|}{ Mean } & \multicolumn{2}{|c|}{ Mean } & \multicolumn{2}{|c|}{ Mean } & \multicolumn{2}{|c|}{ Mean } & \multicolumn{2}{|c|}{ Mean } \\
\hline \multicolumn{2}{|c|}{ Year } & Y1 & Y2 & Y1 & Y2 & Y1 & $\mathrm{Y} 2$ & $\mathrm{Y1}$ & Y2 & Y1 & Y2 & $\mathrm{Y1}$ & Y2 \\
\hline \multirow{2}{*}{ System } & CONV & $100.54 \mathrm{a}$ & $92.92 \mathrm{a}$ & $43.13 \mathrm{~b}$ & $48.25 \mathrm{~b}$ & 5950.24 & $4459.47 \mathrm{~b}$ & $11.96 \mathrm{a}$ & $13.47 \mathrm{a}$ & $89.79 \mathrm{a}$ & $107.83 \mathrm{a}$ & $9.39 \mathrm{a}$ & 10.67 \\
\hline & ORG & $96.80 \mathrm{~b}$ & $89.04 \mathrm{~b}$ & $44.11 \mathrm{a}$ & $49.44 \mathrm{a}$ & 5642.74 & $4719.71 \mathrm{a}$ & $10.19 \mathrm{~b}$ & $12.35 \mathrm{~b}$ & $87.89 \mathrm{~b}$ & $104.83 \mathrm{~b}$ & $7.76 \mathrm{~b}$ & 10.43 \\
\hline \multicolumn{2}{|c|}{$p$-Value } & $\leq 0.0001$ & $\leq 0.0001$ & 0.0341 & $\leq 0.0001$ & 0.062 & 0.0169 & $\leq 0.0001$ & $\leq 0.0001$ & 0.0075 & $\leq 0.0001$ & $\leq 0.0001$ & 0.36 \\
\hline \multirow[b]{2}{*}{ Rate } & Low $\mathrm{N}$ & $96.63 c$ & $88.90 \mathrm{c}$ & 43.64 & 48.62 & 5586.99 & $4053.13 \mathrm{c}$ & $10.45 c$ & $12.14 \mathrm{c}$ & 89.58 & $103.25 c$ & $7.88 \mathrm{~b}$ & $10.01 \mathrm{~b}$ \\
\hline & Med N & $98.64 \mathrm{~b}$ & $91.07 \mathrm{~b}$ & 43.87 & 48.91 & 5954.18 & $4562.20 \mathrm{~b}$ & $11.07 \mathrm{~b}$ & $12.99 \mathrm{~b}$ & 88.27 & $106.17 \mathrm{~b}$ & $8.63 \mathrm{ab}$ & $10.79 \mathrm{a}$ \\
\hline \multicolumn{2}{|c|}{$p$-Value } & $\leq 0.0001$ & $\leq 0.0001$ & 0.55 & 0.27 & 0.091 & $\leq 0.0001$ & $\leq 0.0001$ & $\leq 0.0001$ & 0.38 & $\leq 0.0001$ & 0.0011 & 0.0025 \\
\hline \multirow{3}{*}{ Spray } & No spray & $97.37 \mathrm{~b}$ & $89.75 b$ & 44.13 & $48.79 \mathrm{ab}$ & $6183.05 \mathrm{a}$ & 4505.70 & 11.03 & 12.99 & 88.52 & 106.71 & $8.21 \mathrm{~b}$ & 10.48 \\
\hline & 1 spray & $98.53 \mathrm{ab}$ & $90.91 \mathrm{ab}$ & 43.71 & $49.29 \mathrm{a}$ & $5910.55 \mathrm{a}$ & 4727.57 & 10.96 & 12.84 & 88.95 & 105.98 & $8.17 b$ & 10.53 \\
\hline & 2 sprays & $100.12 \mathrm{a}$ & $92.29 \mathrm{a}$ & 43.01 & $48.46 \mathrm{~b}$ & $5295.85 \mathrm{~b}$ & 4535.50 & 11.23 & 12.88 & 89.04 & 106.31 & $9.35 \mathrm{a}$ & 10.64 \\
\hline \multicolumn{2}{|c|}{$p$-Value } & 0.0086 & 0.0200 & 0.12 & 0.0046 & 0.0005 & 0.18 & 0.091 & 0.47 & 0.78 & 0.22 & 0.0083 & 0.87 \\
\hline
\end{tabular}


Table 4. Mean plant height $(\mathrm{cm})$ and yield $(\mathrm{kg} / \mathrm{ha})$ for system by number of spray interaction. Means with the same letters are not significantly different based on Tukey's HSD test performed at $\alpha=0.05$ for $\mathrm{Y} 1$.

\begin{tabular}{cccc}
\hline System & Spray & Mean Plant Height (cm) & Mean Yield (kg/ha) \\
\hline CONV & No spray & $100.12 \mathrm{a}$ & $7021.08 \mathrm{a}$ \\
CONV & 1 spray & $100.75 \mathrm{a}$ & $5848.21 \mathrm{~b}$ \\
CONV & 2 sprays & $100.75 \mathrm{a}$ & $4981.42 \mathrm{c}$ \\
ORG & No spray & $94.61 \mathrm{c}$ & $5345.03 \mathrm{bc}$ \\
ORG & 1 spray & $96.31 \mathrm{bc}$ & $5972.90 \mathrm{~b}$ \\
ORG & 2 sprays & $99.48 \mathrm{ab}$ & $5610.29 \mathrm{bc}$ \\
\hline
\end{tabular}

\subsection{Yield Traits}

The control spray treatment in the CONV system had greater yield than treatments in the CONV system with one and two sprays; the yield exceeded the yields in the ORG treatments in Y1 (Table 4). No statistical differences were observed between treatments within the ORG system. The CONV one spray treatment did not differ from any ORG treatments, while no statistical differences were observed between the CONV two spray and the ORG no and two spray treatments.

In Y2, treatments in the ORG system had 5.8\% greater yield than treatments in the CONV system, when averaged across all other treatment factors (Table 3). This effect was modified by significant system $\times \mathrm{N}$ rate interactions (Table 2). The ORG system with High $\mathrm{N}$ rate had greater yield than any other system or $\mathrm{N}$ rate combination. No differences were observed between Med, Low and High N-rate treatments within the CONV system or the Med ORG treatment. The ORG Low rate had the lowest yield in Y2 yet did not differ from the Low and Med CONV treatments.

The thousand kernel weight (TKW) was significantly greater in the ORG system than in the CONV in $Y 1$ and $\mathrm{Y} 2$ (2.2\% and $2.4 \%$, respectively) (Table 3$)$. In $Y 2$, plants treated with one spray had a significantly higher TKW than those treated with two sprays, while TKW did not differ statistically in the no spray treatment from one and two sprays (Table 3).

\subsection{Baking Quality}

The baking test results showed that CONV Low $\mathrm{N}$ with two sprays had the highest loaf volume $(630 \mathrm{cc})$, followed by the other CONV treatments (Table 5). The lowest loaf volume was recorded in the ORG High N with two sprays $(595 \mathrm{cc}$ ). The CONV High N treatment with no spray had the greatest loaf height $(79.94 \mathrm{~mm})$ as compared to the CONV Low with no spray, which had the lowest height $(73.5 \mathrm{~mm})$.

Table 5. Bread loaf weight, height and volume from loaf baking trial.

\begin{tabular}{cccccc}
\hline System & Rate & Spray & Loaf wt $(g)$ & Loaf ht (cm) & Loaf Vol (cc) \\
\hline ORG & Low N & No spray & 257 & 76.88 & 600 \\
ORG & Low N & 2 sprays & 254 & 75.8 & 610 \\
ORG & High N & No spray & 263 & 76.97 & 610 \\
ORG & High N & 2 sprays & 261 & 75.78 & 595 \\
CONV & Low N & No spray & 259 & 73.5 & 600 \\
CONV & Low N & 2 sprays & 255 & 75.18 & 630 \\
CONV & High N & No spray & 259 & 79.94 & 620 \\
CONV & High N & 2 sprays & 254 & 77.91 & 625 \\
\hline
\end{tabular}

The protein content was greater in the CONV system than the ORG system in both Y1 and Y2 (17.4\% and 9.1\%, respectively) (Table 3). In Y1, this effect was modified by significant system-rate interactions, in which plants in the CONV system grown with High $\mathrm{N}$ rate had significantly higher protein content and exceeded all other treatments, followed by the CONV Med treatment with 7.7\% (Table 2). The CONV Low N treatment did not differ from the ORG High $N$ treatment, which in its turn did not differ from the ORG Med 
$\mathrm{N}$ treatment. The ORG Low $\mathrm{N}$ treatment had the lowest protein content, although it did not differ from the ORG Med $\mathrm{N}$ treatment.

The predicted lactic acid (SRC\%) was greater in the CONV system than the ORG system during both study years ( $2.2 \%$ in $\mathrm{Y} 2$ and $2.9 \%$ in $\mathrm{Y} 2$ ) (Table 3). In Y2, the SRC $\%$ was greatest in plants grown with the High $\mathrm{N}$ rate, followed by the Med $\mathrm{N}$ and the Low $\mathrm{N}$ rate treatments (Table 3).

Although the data were analyzed separately by year, it is of note that the sedimentation value (SV\%) was greater in Y2 than Y1 in all treatments (Table 3). In Y1, the CONV treatments had higher SV\% than the ORG treatments, however, these did not differ in Y2. Greater SV\% was observed in both years in the High N and Med N rates, though the Med $\mathrm{N}$ did not differ from the High $\mathrm{N}$ in $\mathrm{Y} 1$ (Table 3). Additionally, in Y1, plants sprayed with two sprays had greater $\mathrm{SV} \%$ than treatments with one spray or no sprays.

\section{Discussion}

\subsection{Farming System Affects Grain Yield and Baking Quality}

In both study years, plant heights were significantly affected by system-rate interactions (Table 2). While synthetic fertilizer is known to promote the vigor of plant growth, no difference was observed within means in the CONV treatments. The application of chemical fertilizer at early growth stages can make $\mathrm{N}$ more available to the plant so it encourages the rapid elongation of the cell walls and boosts the plant to reach its height potential [23]. Unlike the CONV system, variation in plant height was observed within the ORG treatments such that the plant height in the ORG High N treatment was not significantly different than all CONV treatments. Organic fertilizers can boost soil structure and physical properties such as porosity, which can improve root growth and the rhizosphere and promote plant growth while also increasing the availability of nutrient sources [24].

Unlike plant height, yields were greater in the ORG system compared to the CONV system in Y2 only (Table 3). This effect was also modified by the interaction with rate in the same year, whereas ORG High $\mathrm{N}$ yielded greater than all other treatments (Table 2). The ORG field site location in Y2 was historically known for low fertility. Therefore, it was densely planted with cover crops for more than two years prior to this study to add more nitrogen to the soil. These multispecies cover crops are known to contribute to soil health and may also have a weed suppressive activity. This may have resulted in less competition for nutrients and greater availability to the plants, especially during green-up, when maximum yield potential can be achieved. Our results align with those of Koutroubas et al. [25], who found that grain yield with the doubling of organic manure $(32 \mathrm{Mg} / \mathrm{ha})$ was similar to that of inorganic fertilizer at the recommended rate $(120 \mathrm{~kg} / \mathrm{ha})$ on their study of the effect of organic manure on wheat grain yield, nutrient accumulation, and translocation.

Thousand kernel weight was also greater in the ORG system than the CONV system in both years (Table 3). Since weed population and disease severity was under economic threshold, especially at the grain filling period, therefore, TKW increased with the decrease in these yield-liming factors [26].

The protein content plays a crucial role in bread baking quality. In both study years, grain from the CONV system had greater protein content than grain from the ORG system (Table 3). This may be attributed to the use of mineral fertilizers that makes the $\mathrm{N}$ form that is more available to plants [27].

The predicted lactic acid SRC (\%) was also greater in the CONV system than in the ORG for both years of study (Table 3). This may be due to the correlation between protein content and lactic acid SRC [28], which is similar to findings reported by Xiao et al. [29]. SRC has been shown to be positively correlated with loaf volume [30], which is consistent with the results reported herein, with treatments in the CONV system reporting greater SRC and loaf volume values compared to treatments in the ORG system (Table 5). Similarly, sedimentation value (SV\%), a predictor of gluten strength, was greater in $\mathrm{Y} 1$ in the CONV system than in the ORG system (Table 3). Sedimentation value is usually correlated positively with protein content [31] and with gluten strength (Castellari and Van Sanford, 
unpublished). In their work on the impact of production system and cultivars of winter wheat, Ceseviciene et al. [32] found that grain grown in conventional farming systems improved grain quality traits and gave higher sedimentation values than organic systems. The positive relationship between SV and loaf volume has been shown to be particularly pronounced when grain protein levels are less than $13 \%[33,34]$. This is consistent with the relationships observed in this study (Table 5), with relatively low protein contents in all treatments, but particularly those grown in the ORG system.

\subsection{Increased Nitrogen Rates Improve Yield and Baking Quality Traits}

The yield and protein content were consistently greater in the High $\mathrm{N}$ treatment, as was SRC in Y2. Greater N application rates are well documented in increasing crop yields [35]. Greater yields may have been observed in the ORG system due to residual N from the previous crop rotation, as discussed above.

Plants grown in CONV system under the High $\mathrm{N}$ rate had significantly greater protein content than in the Med and Low N rate in either the CONV or ORG systems (Table 2). This may due to the well-documented effect of increased fertility levels being generally correlated with increased protein content, as discussed above [36]. Similarly, Mallory and Darby [37] found that late season $\mathrm{N}$ application increased the protein content in HRW. In addition to protein content, we observed improvement in the traits that predict baking quality with increased $\mathrm{N}$ application rates, such as SRC and SV (Table 3). These findings are consistent with Song et al. [38], who found that SV, protein content and other end-use baking qualities were improved by $\mathrm{N}$ application in booting stages in particular.

\subsection{Biofertilizers Had Little Effect on Yield and Baking Quality Traits}

Biofertilizers have been shown to provide sustainable nutrition for plants, as beneficial bacteria and fungi can assist in increasing crop yield in wheat $[39,40]$. In both years, plants recorded maximum height with two sprays but not statistically different than one spray (Table 3). However, this variation in plant height was only true in the ORG system when spraying was modified by the interaction with the system in Y1 (Table 4). Possibly, biofertilizer sprays have a positive effect on plant growth by increasing the absorption of relatively immobile nutrients including $\mathrm{P}, \mathrm{Zn}$ and $\mathrm{Cu}$ from the soil, making them more readily accessible to plants, which promotes sprouting and shoot elongation [41]. In addition, at different stages of plant growth, different mineralization rates and nutrient availability can explain the variable levels of nutrients in the soil amendment [42]. Our findings are in line with Javaid et al. [43], who found that the EM (Effective Microorganisms) application showed a significant effects of shoot systems on wheat plant when they study the effect of heat-sterilization and EM (Effective Microorganisms) application on wheat grown in organic-amended sandy loam soil.

On the other hand, in Y1, biofertilizer had a negative effect on the yield of plants grown in the CONV system (Table 4). To the best of our knowledge, no study has been found so far comparing the effect of biofertilizer on wheat grown in conventional and organic systems. Many factors may be involved in this variation such as the environmental condition during grain filling stage as well as the microbial community level at the site location. The competition between the EM spray and the indigenous rhizobacteria may constrain the positive effect of biofertilizer on yield. Similar results were found by Dal Cortivo et al. [15], who reported that there was no significant improvement in yield with the use of biofertilizer in their study of the seed biofertilizer applied on rhizosphere biodiversity and growth of common wheat in the field. However, this result is in contrast with Kachroo and Razdan [44] and Singh et al. [45], who reported that the use of a 1:1 ratio of Azotobacter + Azospirillum inoculation significantly increased growth and yield in wheat.

In Y1, two sprays with biofertilizer significantly affected the SV (Table 3). It could be the application of biofertilizer improve the nutrients availability in synchrony between the increases in other quality traits such as protein content and lactic acid SRC, as well as the interaction between the environmental condition and genotype. 


\section{Conclusions}

The present study was designed to determine the effect of EM spray application with three different nitrogen regimes in conventional and organically managed system on growth, yield and quality traits of hard red winter wheat in Kentucky. In our study, biofertilizer sprays had little to no effect on ORG yield and a negative effect on conventional yield in Y1. Meanwhile, the ORG system had greater yield than the CONV system in Y2. Baking quality traits (protein content, SRC and SV) were impacted by system and rate, with wheat grown in the CONV system at a High $\mathrm{N}$ rate demonstrating the greatest predicted baking quality. Breads baked from wheat grown in the CONV treatments had consistently greater loaf volume than wheat grown in ORG treatments. Nitrogen fertility rate had consistent effects on baking quality traits, but biofertilizers had minimum to no effect on baking quality traits or yields. From this work, the substitution of biofertilizers for traditional $\mathrm{N}$ fertilizers (conventional or organic) cannot be recommended at this time. However, given the lack of negative effects and potential synergies between manure-based fertilizer used in ORG systems and biofertilizers, additional studies should be conducted to explore the optimum biofertilizer use in organic farming system on wheat yield and protein content and composition.

Author Contributions: Conceptualization, A.A.-Z. and D.V.S.; methodology, D.V.S.; formal analysis, A.A.-Z.; writing—original draft preparation, A.A.-Z.; writing—review and editing, K.J., D.V.S., M.A.W. and T.P.; supervision, K.J. All authors have read and agreed to the published version of the manuscript.

Funding: This research received no external funding.

Institutional Review Board Statement: Not applicable.

Informed Consent Statement: Not applicable.

Data Availability Statement: The data presented in this study are available on request from the corresponding author.

Acknowledgments: We thank Mohammed Dawood, Matthew Hazzard, John Connelley, Steve Diver and Sandy Swanson for technical and logistics assistance. We thank Maria Paula Castellari for assistance with bread dough preparation. EM (AG1000) was provided by TeraGanix company.

Conflicts of Interest: The authors declare no conflict of interest. 


\section{Appendix A}

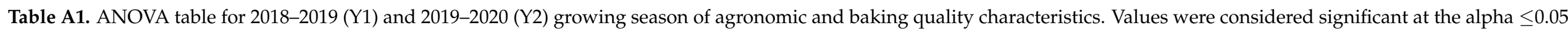
level, with non-significant effects indicated by annotation as "ns".

\begin{tabular}{|c|c|c|c|c|c|c|c|c|c|c|c|c|c|}
\hline \multirow{3}{*}{$\begin{array}{c}\begin{array}{c}\text { Source of } \\
\text { Variance }\end{array} \\
\text { Year }\end{array}$} & \multirow{3}{*}{ DF } & \multicolumn{2}{|c|}{ Plant Height $(\mathrm{cm})$} & \multicolumn{2}{|c|}{ Yield (kg/ha) } & \multicolumn{2}{|c|}{$\mathrm{TKW}^{\dagger}(\mathrm{g})$} & \multicolumn{2}{|c|}{ Protein Content \% } & \multicolumn{2}{|c|}{ SRC $\ddagger \%$} & \multicolumn{2}{|c|}{$\mathrm{SV}^{¥}(\mathrm{~mL})$} \\
\hline & & \multicolumn{2}{|c|}{$p$-Value } & \multicolumn{2}{|c|}{$p$-Value } & \multicolumn{2}{|c|}{$p$-Value } & \multicolumn{2}{|c|}{$p$-Value } & \multicolumn{2}{|c|}{$p$-Value } & \multicolumn{2}{|c|}{$p$-Value } \\
\hline & & Y1 & Y2 & Y1 & $\mathrm{Y} 2$ & Y1 & $\mathrm{Y} 2$ & $\mathrm{Y1}$ & Y2 & $\mathrm{Y1}$ & Y2 & $\mathrm{Y1}$ & Y2 \\
\hline N Rate & 2 & $<0.0001$ & $<0.0001$ & $0.091 \mathrm{~ns}$ & $<0.0001$ & $0.5517 \mathrm{~ns}$ & $0.2773 \mathrm{~ns}$ & $<0.0001$ & $<0.0001$ & $0.3884 \mathrm{~ns}$ & $<0.0001$ & 0.0011 & 0.0025 \\
\hline System & 1 & $\leq 0.0001$ & $\leq 0.0001$ & $0.062 \mathrm{~ns}$ & 0.0169 & 0.0341 & $\leq 0.0001$ & $\leq 0.0001$ & $\leq 0.0001$ & 0.0075 & $\leq 0.0001$ & $\leq 0.0001$ & $0.3601 \mathrm{~ns}$ \\
\hline Spray & 2 & 0.0086 & 0.0200 & 0.0005 & $0.1861 \mathrm{~ns}$ & $0.1251 \mathrm{~ns}$ & 0.0046 & $0.0918 \mathrm{~ns}$ & $0.4700 \mathrm{~ns}$ & $0.7804 \mathrm{~ns}$ & $0.2298 \mathrm{~ns}$ & 0.0083 & $0.8719 \mathrm{~ns}$ \\
\hline N Rate * System & 2 & 0.0001 & 0.0004 & $0.3075 \mathrm{~ns}$ & 0.0104 & $0.3553 \mathrm{~ns}$ & $0.2773 \mathrm{~ns}$ & 0.0020 & $0.6873 \mathrm{~ns}$ & $0.4763 \mathrm{~ns}$ & $0.1315 \mathrm{~ns}$ & $0.3856 \mathrm{~ns}$ & $0.6164 \mathrm{~ns}$ \\
\hline N Rate * Spray & 4 & $0.1805 \mathrm{~ns}$ & $0.2280 \mathrm{~ns}$ & $0.1889 \mathrm{~ns}$ & $0.5652 \mathrm{~ns}$ & $0.2959 \mathrm{~ns}$ & $0.0751 \mathrm{~ns}$ & $0.9026 \mathrm{~ns}$ & $0.6873 \mathrm{~ns}$ & $0.6846 \mathrm{~ns}$ & $0.6366 \mathrm{~ns}$ & $0.1390 \mathrm{~ns}$ & $0.5489 \mathrm{~ns}$ \\
\hline System * Spray & 2 & 0.0371 & $0.0790 \mathrm{~ns}$ & $\leq 0.0001$ & $0.2945 \mathrm{~ns}$ & $0.7664 \mathrm{~ns}$ & $0.3676 \mathrm{~ns}$ & $0.1331 \mathrm{~ns}$ & $0.1020 \mathrm{~ns}$ & $0.8700 \mathrm{~ns}$ & $0.0942 \mathrm{~ns}$ & $0.2319 \mathrm{~ns}$ & $0.2150 \mathrm{~ns}$ \\
\hline $\begin{array}{c}\text { N Rate * System } \\
* \text { Spray }\end{array}$ & 4 & $0.5180 \mathrm{~ns}$ & $0.5820 \mathrm{~ns}$ & $0.4102 \mathrm{~ns}$ & $0.4670 \mathrm{~ns}$ & $0.7697 \mathrm{~ns}$ & $0.3231 \mathrm{~ns}$ & $0.4419 \mathrm{~ns}$ & $0.4388 \mathrm{~ns}$ & $0.7187 \mathrm{~ns}$ & $0.5988 \mathrm{~ns}$ & $0.8026 \mathrm{~ns}$ & $0.2968 \mathrm{~ns}$ \\
\hline
\end{tabular}

${ }^{+}$TKW—-Thousand kernel weight. ${ }^{\ddagger}$ SRC—Solvent retention capacity. ${ }^{*}$ SV—Sedimentation value. 


\section{References}

1. Plains Grains, I. Hard Red Winter Wheat, 2019 Regional Quality Survey. Available online: https://www.plainsgrains.org/wpcontent/uploads/2019/11/Plains-Grains-2019-Winter-Wheat-Report-Web.pdf (accessed on 13 April 2021).

2. USDA-NASS. Small Grains 2020 Summary; USDA National Agricultural Statistics Service: Washington, DC, USA, 2020.

3. May, L.; Van Sanford, D.; Finney, P. Soft wheat milling and baking quality in a soft red winter $x$ hard red winter wheat population. Cereal Chem. 1989, 66, 378-381.

4. Lee, C.; Herbek, J. A Comprehensive Guide to Wheat Management in Kentucky; University of Kentucky, College of Agriculture: Lexington, KY, USA, 2009; pp. 13-19.

5. Carson, G.R.; Edwards, N.M. Criteria of wheat and flour quality. In Wheat: Chemistry and Technology, 4th ed.; Khan, K., Peter, R., Shewry, P.R., Eds.; Cereals \& Grains Association: Saint Paul, MN, USA, 2009; pp. 97-118.

6. Clark, A. Managing Cover Crops Profitably; Diane Publishing: Collingdale, PA, USA, 2008.

7. Hills, K.M.; Goldberger, J.R.; Jones, S.S. Commercial Bakers' View on the Meaning of "Local" Wheat and Flour in Western Washington State. J. Agric. Food Syst. Community Dev. 2013, 3, 13-32. [CrossRef]

8. Zapata, F. Introduction to Nitrogen Management in Agricultural Systems; Technical report: IAEA-TCS-29/CD; International Atomic Energy Agency: Seibersdorf, Austria, 2008.

9. Sahoo, R.K.; Bhardwaj, D.; Tuteja, N. Biofertilizers: A sustainable eco-friendly agricultural approach to crop improvement. In Plant Acclimation to Environmental Stress; Springer: Berlin/Heidelberg, Germany, 2013; pp. 403-432.

10. Praveen, K.; Singh, A. Realizing the potential of a low-cost technology to enhance crop yields: Evidence from a meta-analysis of biofertilizers in India. Agric. Econ. Res. Rev. 2019, 32, 77-91. [CrossRef]

11. Jacoby, R.; Peukert, M.; Succurro, A.; Koprivova, A.; Kopriva, S. The role of soil microorganisms in plant mineral nutritionCurrent knowledge and future directions. Front. Plant Sci. 2017, 8, 1617. [CrossRef]

12. Karthikeyan, B.; Joe, M.M.; Jaleel, C.A.; Deiveekasundaram, M. Effect of root inoculation with plant growth promoting rhizobacteria (PGPR) on plant growth, alkaloid content and nutrient control of Catharanthus roseus (L.) G. Don. Nat. Croat. $2010,19,205$.

13. Khalid, M.; Hassani, D.; Bilal, M.; Asad, F.; Huang, D. Influence of bio-fertilizer containing beneficial fungi and rhizospheric bacteria on health promoting compounds and antioxidant activity of Spinacia oleracea L. Bot. Stud. 2017, 58, 1-9. [CrossRef] [PubMed]

14. Taie, H.A.; El-Mergawi, R.; Radwan, S. Isoflavonoids, flavonoids, phenolic acids profiles and antioxidant activity of soybean seeds as affected by organic and bioorganic fertilization. Am. Eurasian J. Agric. Environ. Sci. 2008, 4, $207-213$.

15. Dal Cortivo, C.; Ferrari, M.; Visioli, G.; Lauro, M.; Fornasier, F.; Barion, G.; Panozzo, A.; Vamerali, T. Effects of seed-applied biofertilizers on rhizosphere biodiversity and growth of common wheat (Triticum aestivum L.) in the field. Front. Plant Sci. 2020, 11, 72. [CrossRef]

16. Bhardwaj, D.; Ansari, M.W.; Sahoo, R.K.; Tuteja, N. Biofertilizers function as key player in sustainable agriculture by improving soil fertility, plant tolerance and crop productivity. Microb. Cell Factories 2014, 13, 1-10. [CrossRef]

17. Large, E.C. Growth stages in cereals illustration of the Feekes scale. Plant Pathol. 1954, 3, 128-129. [CrossRef]

18. Meier, U. Growth Stages of Mono-And Dicotyledonous Plants; Blackwell Wissenschafts-Verlag: Hoboken, NJ, USA, 1997.

19. USDA. National Organic Program. Available online: https://www.ams.usda.gov/sites/default/files/media/NOP\%20 Preamble\%20Full\%20Version.pdf (accessed on 5 December 2021).

20. Hrušková, M.; Škodová, V.; Blažek, J. Wheat sedimentation values and falling number. Czech J. Food Sci. 2004, 22, 51. [CrossRef]

21. Dick, J.; Quick, J. A modified screening test for rapid estimation of gluten strength in early-generation durum wheat breeding lines. Cereal Chem. 1983, 60, 315-318.

22. Teferra, T.F. Laboratory Manual for Engineering Properties of Foods; Hawassa University: Awassa, Ethiopia, 2013.

23. Kobua, C.K.; Jou, Y.-T.; Wang, Y.-M. Advantages of Amending Chemical Fertilizer with Plant-Growth-Promoting Rhizobacteria under Alternate Wetting Drying Rice Cultivation. Agriculture 2021, 11, 605. [CrossRef]

24. Goss, M.J.; Tubeileh, A.; Goorahoo, D. A review of the use of organic amendments and the risk to human health. Adv. Agron. 2013, 120, 275-379.

25. Koutroubas, S.D.; Antoniadis, V.; Damalas, C.A.; Fotiadis, S. Effect of organic manure on wheat grain yield, nutrient accumulation, and translocation. Agron. J. 2016, 108, 615-625. [CrossRef]

26. David, C.; Jeuffroy, M.-H.; Henning, J.; Meynard, J.-M. Yield variation in organic winter wheat: A diagnostic study in the Southeast of France. Agron. Sustain. Dev. 2005, 25, 213-223. [CrossRef]

27. Mäder, P.; Hahn, D.; Dubois, D.; Gunst, L.; Alföldi, T.; Bergmann, H.; Oehme, M.; Amadò, R.; Schneider, H.; Graf, U. Wheat quality in organic and conventional farming: Results of a 21 year field experiment. J. Sci. Food Agric. 2007, 87, 1826-1835. [CrossRef]

28. Hammed, A.M.; Ozsisli, B.; Ohm, J.B.; Simsek, S. Relationship between solvent retention capacity and protein molecular weight distribution, quality characteristics, and breadmaking functionality of hard red spring wheat flour. Cereal Chem. 2015, 92, 466-474. [CrossRef]

29. Xiao, Z.; Park, S.H.; Chung, O.; Caley, M.; Seib, P. Solvent retention capacity values in relation to hard winter wheat and flour properties and straight-dough breadmaking quality. Cereal Chem. 2006, 83, 465-471. [CrossRef]

30. Aghagholizadeh, R.; Kadivar, M.; Nazari, M.; Ahmadi, H.; Azizi, M.H. Capability of solvent retention capacity to quality of flat bread in three wheat cultivars. J. Food Sci. Technol. 2019, 56, 775-782. [CrossRef] 
31. Seabourn, B.W.; Xiao, Z.S.; Tilley, M.; Herald, T.J.; Park, S.H. A Rapid, Small-Scale Sedimentation Method to Predict Breadmaking Quality of Hard Winter Wheat. Crop. Sci. 2012, 52, 1306-1315. [CrossRef]

32. Ceseviciene, J.; Slepetiene, A.; Leistrumaite, A.; Ruzgas, V.; Slepetys, J. Effects of organic and conventional production systems and cultivars on the technological properties of winter wheat. J. Sci. Food Agric. 2012, 92, 2811-2818. [CrossRef] [PubMed]

33. Preston, K.; March, P.; Tipples, K. An assessment of the SDS-sedimentation test for the prediction of Canadian bread wheat quality. Can. J. Plant Sci. 1982, 62, 545-553. [CrossRef]

34. Ayoub, M.; Smith, D.; Fregeau-Reid, J. Evaluation of the SDS-sedimentation test for the assessment of eastern Canadian bread wheat quality. Can. J. Plant Sci. 1993, 73, 995-999. [CrossRef]

35. Campillo, R.; Jobet, C.; Undurraga, P. Effects of nitrogen on productivity, grain quality, and optimal nitrogen rates in winter wheat cv. Kumpa-INIA in Andisols of Southern Chile. Chil. J. Agric. Res. 2010, 70, 122-131. [CrossRef]

36. Miller, P.; Lighthiser, E.; Jones, C.; Holmes, J.; Rick, T.; Wraith, J. Pea green manure management affects organic winter wheat yield and quality in semiarid Montana. Can. J. Plant Sci. 2011, 91, 497-508. [CrossRef]

37. Mallory, E.B.; Darby, H. In-season nitrogen effects on organic hard red winter wheat yield and quality. Agron. J. 2013, 105, 1167-1175. [CrossRef]

38. Song, L.; Li, L.; Zhao, L.; Liu, Z.; Li, X. Effects of Nitrogen Application in the Wheat Booting Stage on Glutenin Polymerization and Structural-Thermal Properties of Gluten with Variations in HMW-GS at the Glu-D1 Locus. Foods 2020, 9, 353. [CrossRef]

39. Basu, S.; Rabara, R.; Negi, S. Towards a better greener future-an alternative strategy using biofertilizers. I: Plant growth promoting bacteria. Plant Gene 2017, 12, 43-49. [CrossRef]

40. Igiehon, N.O.; Babalola, O.O. Biofertilizers and sustainable agriculture: Exploring arbuscular mycorrhizal fungi. Appl. Microbiol. Biotechnol. 2017, 101, 4871-4881. [CrossRef]

41. Patra, B.; Singh, J. A review: Usage of biofertilizer in cereal crops. Curr. J. Appl. Sci. Technol. 2019, 36, 1-8. [CrossRef]

42. Kautz, T.; López-Fando, C.; Ellmer, F. Abundance and biodiversity of soil microarthropods as influenced by different types of organic manure in a long-term field experiment in Central Spain. Appl. Soil Ecol. 2006, 33, 278-285. [CrossRef]

43. Javaid, A.; Bajwa, R.; Anjum, T. Effect of heat-sterilization and EM (effective microorganisms) application on wheat (Triticum aestivum L.) grown in organic-amended sandy loam soil. Cereal Res. Commun. 2008, 36, 489-499. [CrossRef]

44. Kachroo, D.; Razdan, R. Growth, nutrient uptake and yield of wheat (Triticum aestivum) as influenced by biofertilizers and nitrogen. Indian J. Agron. 2006, 51, 37-39.

45. Singh, N.; Chaudhary, F.; Patel, D. Effectiveness of Azotobacter bio-inoculant for wheat grown under dryland condition. J. Environ. Biol. 2013, 34, 927. [PubMed] 